\title{
The prevalence of seropositivity to hepatitis B surface antigen and the corresponding hemato-biochemical features in sickle cell patients in Ghana
}

\author{
Nsiah K. ${ }^{1}$, Dzogbefia V.P. ${ }^{1}$, Osei-Akoto A. ${ }^{2}$, Ansong D. ${ }^{2}$ \\ 1. Department of Biochemistry and Biotechnology, Kwame Nkrumah University of Science and Technology, (KNUST), \\ Kumasi, Ghana. 2. Department of Child Health, School of Medical Sciences, KNUST, Kumasi, Ghana.
}

Correspondence: Nsiah, K. Address: Department of Biochemistry and Biotechnology, Kwame Nkrumah University of Science and Technology, (KNUST), Kumasi, Ghana. E-mail: knsiah.cos@knust.edu.gh

Received: January 4, 2012

Accepted: February 13, $2012 \quad$ Published: March 1, 2012

DOI : $10.5430 /$ jhm.v2n1p13

URL: http://dx.doi.org/10.5430/jhm.v2n1p13

\begin{abstract}
Objectives: The reported prevalence of HBsAg in the general Ghanaian population is high (more than 10\%). However, it is anticipated that following the establishment of the Sickle Cell Clinic, due to the comprehensive care, the prevalence of HBsAg among the sickle cell patients should be lower.

Method: This study was aimed at screening for the HBsAg in 330 sickle cell patients, as well as using some hematobiochemical parameters to characterize the seropositives, relative their age-, sex- and genotype-matched seronegative counterparts.
\end{abstract}

Results: Twelve of the subjects (3.6\%) were seropositive; 6 males and 6 females, this was lower than the prevalence rates reported from the general population. The mean levels of the following indices were higher in the seropositives; ALT (28.3 \pm 19.6 U/L), AST $(52.9 \pm 36.1 \mathrm{U} / \mathrm{L})$, ALP $(181.4 \pm 98.1 \mathrm{U} / \mathrm{L})$, LDH $(1010 \pm 223.5 \mathrm{U} / \mathrm{L})$, albumin $(4.4 \pm 0.5 \mathrm{~g} / \mathrm{dL})$, creatinine $(76.0 \pm 18.2 \mu \mathrm{mol} / \mathrm{L})$, urea $(4.4 \pm 5.8 \mathrm{mmol} / \mathrm{L})$ and platelets $\left(401.3 \pm 152.8 \times 10^{9} / \mathrm{L}\right)$. However, it was only the difference in the mean creatinine levels that reached statistical significance $(P=0.039)$. The cases of seropositivity to HBsAg were not active HBV infection, as patients did not show any incriminating symptoms, apart from vaso-occlusive pain. Additionally, the hematologic and biochemical profiles of both groups were similar.

Conclusion: Compared to the reports from the general Ghanaian population, the prevalence of HBsAg seropositivity has been shown to be lower, and despite the seropositivity, the hepatic and kidney functions had not been compromised.

\section{Key words}

Sickle cell disease, HBsAg, Seropositivity, Prevalence

\section{Introduction}

As a result of the instability of Hbs of sickle cell patients, the red cells are susceptible to lysis, leading to anemic crises, which in many cases have to be corrected by blood transfusion. One problem associated with transfusion is the use of improperly screened donor blood, allowing the transmission of blood-borne viruses like hepatitis B. The virus may also be spread by contact with body secretions such as saliva, sweat, tears, breast milk, semen and pathologic effusions ${ }^{[1]}$. 
An approximately 15\% prevalence of chronic hepatitis B virus carriage has been found in asymptomatic blood donors ${ }^{[2]}$, and $22.9 \%$ among the general Ghanaian population in a selected rural district ${ }^{[3]}$. Among some 1368 unselected pregnant women in Kumasi, also in Ghana, the prevalence was $16 \%{ }^{[4]}$.

Because of the comprehensive care given to sickle cell patients at the Sickle Cell Clinic, established in 1995, the education given to patients, parents/caregivers and healthcare providers would tend to reduce behaviors or practices that would pose risk to sickle cell patients. Therefore, we hypothesise that the prevalence of HBsAg in the sickle cell patients should be lower, compared to the general population, who lack any such special care.

HBsAg appears before the onset of symptoms, and concentration reaches a peak during acute disease and then usually declines to undetectable levels in three to six months ${ }^{[1,5]}$. The persistence of HBsAg beyond six months is indicative of chronic infection.

Serum tests of acute hepatocellular injury are commonly used to monitor the progress of liver disease ${ }^{[6]}$. The release of cytoplasmic proteins from damaged hepatocytes into the vascular system precedes tissue necrosis caused by, for example, viral infections, drug intoxication, ischemia and reperfusion injury, or rejection after liver transplantation ${ }^{[7]}$.

In this study, we screened for the HBsAg in some sickle cell patients, and also determined some hematological indices, liver and kidney function tests, for a comparison between the seropositives and negatives. No such study has been reported in literature, on our sickle cell patients; moreso, following the setting up of the Sickle Cell Clinic, at the Komfo Anokye Teaching Hospital, in Kumasi, Ghana. The study is also important, as it allows the patients, caregivers, as well as healthcare providers know the HBsAg status of patients, for the appropriate precautionary measures to be taken.

\section{Method}

The screening for seropositivity of HBsAg was carried out, using a lateral flow immunoassay test strip, ACON® HBsAg test kit (ACON Laboratories, 4108 Sorrento Valley Boulevard, San Diego, CA 92121, USA). For those found to be positive for HBsAg, liver and kidney function tests and some hematological indices were measured and compared with sex- and age-matched seronegative counterparts. The parameters determined included albumin, alanine aminotransferase (ALT), aspartate aminotransferase (AST), lactate dehydrogenase (LDH) and alkaline phosphatase (ALP). The other parameters were total bilirubin, albumin, total protein, urea and creatinine. These were determined using kits supplied by Human Gesellschaft fùr Biochemica und Diagnostica mbH, Max-Planck-Ring 21-D-65205, Wiesbaden-Germany. The hematological indices included hemoglobin levels, red cells, white cells and platelets, and were determined using Cell Dyn 1800 (Abbott Inc., USA). The reticulocyte count was manually done.

\section{Statistical analysis}

Data on quantitative variables were statistically analysed using Statsgraphics 2006 (StatPoint Inc, USA), to obtain means and standard deviations, as well as test of significance between means.

\section{Results}

Out of the 330 patients screened, twelve of them (about 3.6\%) were positive for HBsAg.

There were six males and six females, with ages between 10 and 18 years. There were two positive cases for subjects of the following ages; 10, 14, 15, 16, 17 and 18 years. Since the seronegatives were age-matched with the seropositives, the ages 
of the two groups were the same. This was done to avoid age being a confounding factor in the study. Seven of the seropositives were SS, four of SC genotypes, and one of an unspecified genotype. Considering the two main genotypes, SS and SC, the prevalence rates for the surface antigens were about 3.7\% (7/189) and 3.8\% (4/104), respectively.

\section{Hematological profile of seropositive patients}

There was one case of leucopenia in one of the subjects with HBsAg who showed a minimum white cell count of $3.6 \times$ $10^{9} / \mathrm{L}$, otherwise the two groups showed similar hematological profiles (Table 1 ), as the differences between the mean levels of red blood cells, white blood cells, reticulocytes and platelets were not significant. It is the difference between the platelet counts that approached significance. The mean hemoglobin levels, showed the patients of the two groups were mildly anemic, and were leucocytotic, with their mean WBC counts above $10 \times 10^{9} / \mathrm{L}$.

Table 1. Hematological profiles of SCD subjects with/without HBsAg

\begin{tabular}{llllllllll}
\hline \multicolumn{1}{l}{ HBsAg+ } \\
& Min & Max & Mean & SD & Min & Max & Mean & SD & $P$ \\
Hb $(g / d L)$ & 4.2 & 11.2 & 8.3 & 1.97 & 5.6 & 13.2 & 8.5 & 2.05 & 0.785 \\
RBCs $\left(\times 10^{12} / \mathrm{L}\right)$ & 1.360 & 3.680 & 2.992 & 0.739 & 1.470 & 4.140 & 2.959 & 0.777 & 0.923 \\
Reticulocytes $(\%)$ & 2 & 55 & 19.6 & 18.6 & 5 & 55 & 20.5 & 14.2 & 0.896 \\
WBCs $\left(\times 10^{9} / \mathrm{L}\right)$ & 3.6 & 39.1 & 12.3 & 9.8 & 5.1 & 27.5 & 13.1 & 6.2 & 0.824 \\
Platelets $\left(\times 10^{9} / \mathrm{L}\right)$ & 201 & 611 & 401.3 & 152.8 & 90 & 493 & 289.5 & 124.4 & 0.080 \\
\hline
\end{tabular}

\section{The biochemical indices}

The mean levels of the following biochemical indices were higher in the seropositives (Table 2); ALT, AST, ALP, LDH, albumin, creatinine, urea. However, it was only the difference in the mean creatinine levels that reached statistical significance $(P=0.039$ ). Those cases of seropositivity to HBsAg were not active HBV, as patients had not shown any symptoms, apart from vaso-occlusive pain.

Table 2. Biochemical profiles of SCD subjects with/without HBsAg

\begin{tabular}{llllllllll}
\hline \multicolumn{7}{l}{ HBsAg+ } & \multicolumn{7}{c}{ HBsAg- } \\
& Min & Max & Mean & SD & Min & Max & Mean & SD & $P$ \\
AST (U/L) & 20 & 154 & 52.9 & 36.1 & 12 & 64 & 43.6 & 12.7 & 0.407 \\
ALT (U/L) & 10 & 84 & 28.3 & 19.6 & 11 & 37 & 20.6 & 6.9 & 0.209 \\
ALP (U/L) & 70 & 387 & 181.4 & 98.1 & 50 & 274 & 121.7 & 67.9 & 0.0968 \\
LDH (U/L) & 780 & 1341 & 1010 & 223.5 & 486 & 1576 & 982 & 362.3 & 0.872 \\
Total protein $(\mathrm{g} / \mathrm{dL})$ & 6.5 & 7.8 & 7.3 & 0.4 & 6.4 & 8.4 & 7.5 & 0.5 & 0.319 \\
Albumin $(g / \mathrm{dL})$ & 3.1 & 4.9 & 4.4 & 0.5 & 3.3 & 4.8 & 4.2 & 0.5 & 0.541 \\
Tbilirubin $(\mu \mathrm{mol} / \mathrm{L})$ & 13.4 & 44.6 & 25.4 & 9.13 & 9.3 & 278 & 52.6 & 76.3 & 0.233 \\
Creatinine $(\mu \mathrm{mol} / \mathrm{L})$ & 48.7 & 116.9 & 76.0 & 18.2 & 34.8 & 98.2 & 57.3 & 18.4 & $0.039 *$ \\
Urea (mmol/L) & 1.7 & 22.5 & 4.4 & 5.8 & 2.0 & 7.0 & 3.4 & 1.3 & 0.560 \\
\hline * Statistically significant difference & & & & & & & & &
\end{tabular}




\section{Discussion}

The fact that equal number of males and females had the HBsAg antigen means there is no gender predeliction. Since the infection was not found in any of the subjects below ten years, there was probably no vertical transfer; mother-to-child transmission. It has been shown, mainly in countries with high prevalence rates ${ }^{[8]}$ that almost $90 \%$ of infants born to asymptomatic carrier mothers who also have HBeAg, and approximately 30\% of children infected before 6 years of age become HBsAg carriers. Zhang et al. ${ }^{[9]}$ had observed that materno-fetal transmission seems to play a minor role in Africa, in contrast to what happens in other high-prevalence endemic areas such as South East Asia.

The acquisition through blood transfusion is not likely due to the rigorous screening in the blood bank. It is also possible some of the patients have not had blood transfusion before. For example, a study in Nigeria ${ }^{[10]}$ in which 11 out of 170 SCD patients (6.47\%) were seropositive for HBsAg, none of them had received blood transfusion prior to the study.

A study in a Saudi Arabian population ${ }^{[11]}$ found a prevalence of HBsAg (4.4\% and 4.8\%) in females and males. It had been inferred from this Saudi study that the infection was acquired early in life, a pattern characteristic of areas of high prevalence of the infection. The cause of the infection was ascribed to serum-sharing, associated with close personal contact and oozing dermatologic lesions that occur early in childhood ${ }^{[11]}$. In another study carried out in a rural setting in Ghana, Martinson et al. ${ }^{[3]}$ supported the horizontal transmission mode and gave the behaviors most strongly associated with the transmission to include sharing of towels, sharing of chewing gum or partially eaten candies, bitting the finger nails and scratching the backs of carriers.

Compared to other studies carried out in the general population in this country, the seroprevalence found in the sickle cell patients appears lower. An approximately 15\% prevalence of chronic hepatitis B virus carriage had been found in asymptomatic blood donors ${ }^{[2]}$, and $22.9 \%$ among the general population in a selected rural district ${ }^{[3]}$. Among some 1368 unselected pregnant women in Kumasi, the prevalence was $16 \%{ }^{[4]}$.

The lower prevalence of the surface antigenemia, compared to the general population, could be attributed to a better education of the sickle cell patients, and caregivers on the general upkeep of these patients, in hospital, home, school or work place. The prevalence of 3.7\% for the SS patients and 3.8\% for the SC are almost the same, an indication that patients of both genotypes have equal susceptibilities to the infection.

It could be argued that our study group has a lower prevalence of hepatitis B because people between the age 10-18 are less sexually active, hence have been less exposed to sexually transmitted diseases, like hepatitis B and HIV. The subjects of the study of Martinson et al. ${ }^{[3]}$ were children of age fifteen years or younger. This means the age profile of this group was similar to our study population. On the other hand, the ages in studies ${ }^{[2]}$ and ${ }^{[4]}$ were higher. For example, study ${ }^{[4]}$ involved pregnant mothers, except that their ages were not given. All these pregnant women were negative for anti-HIV; thus HIV virus infection was absent, and so could not have contributed to the high seropositivity for the surface antigen. It was the study by Sarkodie et al. ${ }^{[2]}$, involving volunteer blood donors, of median age 18 years that Anti-HIV was detected in $0.3 \%$ of the donors. But even in this case, comparing the $15.7 \%$ seropositivity for the surface antigen to the very low prevalence of the HIV antibodies, the causality between the HIV infection and hepatitis is very low in our environment.

Vichinsky et al. ${ }^{[12]}$ defined active hepatitis $\mathrm{B}$ as liver function tests above the normal range, together with a positive antigen (HBsAg, HBeAg) test or positive IgM core antibody test, in conjunction with a negative HBsAb test. In our study, the only serological marker measured was the surface antigen. HBsAg appears before the onset of symptoms, and concentration reaches a peak during acute disease and then usually declines to undetectable levels in three to six months ${ }^{[1,}$

${ }^{5]}$. The persistence of HBsAg beyond six months is indicative of chronic infection.

For the one antigenemic who was leucopenic, we cannot attribute this to the viral infection. The mean reticulocyte counts were indicative of brisk erythropoietic activity, despite the presence of the antigen. The almost significantly higher mean 
platelet level for the antigenemic was a further indication of the null effect of the presence of the virus on hemopoietic activity.

It can be seen from Table 1 that the minimum and maximum platelet counts of the seronegatives were lower. In fact, the minimum platelet count in the seronegatives was even in the thrombocytopenic range $\left(<150 \times 10^{9} / \mathrm{L}\right)$, and this could have contributed to the lower mean value for the seronegatives.

Haut et al. ${ }^{[18]}$ had noted that platelet count were moderately elevated during asymptomatic periods, becomes lower in crisis but markedly elevated post-crisis. Factors unattributable to the viral infection are highly probable, but because these were not the subject for the study, we did not go into these.

For the seropositive patients, the ALT activities of two of them were above the upper range of normal (42 and $184 \mathrm{U} / \mathrm{L}$ ), but all the seronegatives had normal values. However, the AST levels were generally higher than ALT. While the AST levels of 8 of the seropositives were above normal, 7 of the seronegatives were above normal. According to Owusu Ofori et al. ${ }^{[13]}$, the overall ratio of elevated ALT among HBsAg-carrying Ghanaian blood donors was 1:10 or 10\%, and in this rather small population of SCPs, only one out of twelve (8.3\%) had ALT level higher than $60 \mathrm{U} / \mathrm{L}$, an arbitrary cut-off level set by local clinicians.

Liver disease is the most important cause of increased ALT activity, and a common cause of increased AST activity ${ }^{[14]}$. Elevation of AST has also been attributed to intravascular hemolysis ${ }^{[14]}$, likewise the elevation of LDH. Because the sickle cell condition is associated with hemolytic tendencies, the levels of AST and LDH reflect the extent of the red cell breakdown.

It has to be pointed out, however, that the magnitude of the increases was not of any clinical significance. The upper normal limits for the aminotransferases have been set at $40 \mathrm{U} / \mathrm{L}^{[15]}$, and according to Sherwood et al. ${ }^{[16]}$, it is levels at least two times above the upper limit that merit clinical consideration.

The only index in which the antigenemic had significantly increased mean level was creatinine, but in this case too, the clinical significance, in relation to renal dysfunction, was quite remote, due to the marginal increase. It has to be pointed out that the highest level of creatinine, $116.9 \mu \mathrm{mol} / \mathrm{L}$ and urea, $22.5 \mathrm{mmol} / \mathrm{L}$ (Table 2), were found in one of the antigenemic patients who also had orchitis, a swelling and pain of the testis, caused by an inflammation of the testis, probably resulting from hematogenous spread during a systemic bacterial or viral illness ${ }^{[17]}$.

In conclusion, the prevalence of HBsAg in some SCPs in our Sickle Cell Clinic, has been found to be lower than the prevalence in the general population. For the seropositives, despite the presence of the hepatitis B infection, the hepatic and kidney functions, based on the tests performed, had not been compromised.

\section{Acknowledgements}

The authors are grateful to the Research and Conferences Committee of KNUST for financial support for this study. Our appreciation also goes to Mr Caleb Firempong and the technical team of the Clinical Analyses Laboratory of the Department of Biochemistry and Biotechnology, for their assistance in the biochemical analyses. For the hematological analyses, we are thankful to Mr B.A. Eshun and his co-workers at the Department of Hematology, Komfo Anokye Teaching Hospital, Kumasi.

This work was presented at the Second Scientific Conference of the College of Health Sciences, University of Ghana, Legon, at the International Conference Centre, Accra; September 24-26, 2008. 


\section{Conflict of interest}

The author declares that there is no conflict of interest statement.

\section{References}

[1] Crawford, J.M. Liver and biliary tract. In: Kumar, V., Abbas, A.K. and Fausto, N. (eds). Robbins and Cotran Pathologic Basis of Disease. 7th ed. Elsevier, Saunders. 2005

[2] Sarkodie F, Adarkwa M, Adu-Sarkodie Y, Candotti D, Acheampong JW, Allain J-P. Screening for viral markers in volunteer and replacement blood donors in West Africa. Vox Sang. 2001;80:142-47. PMid:11840974 http://dx.doi.org/10.1046/j.1423-0410.2001.00023.x

[3] Martinson FE, Weigle KA, Royce RA, Weber DJ, Suchindran CM, Lemon SM. Risk factors for horizontal transmission of hepatitis B virus in a rural district in Ghana. Am J Epidemiol. 1998;147:478-87. PMid:9525535

[4] Candotti D, Danso K, Allain J-P. Maternofetal transmission of hepatitis B genotype E in Ghana, West Africa. J Gen Virol. 2007; 88:2686-95. PMid:17872520 http://dx.doi.org/10.1099/vir.0.83102-0

[5] Calbreath DF. Clinical Chemistry: A Fundamental Textbook, W.B. Saunders Company. 1992;233-38

[6] Dufour DR, Lott JA, Nolte FS, Gretch DR, Koff RS, Seeff LB. Diagnosis andmonitoring of hepatic injury. I. Performance characteristics of laboratory tests. Clin Chem. 2000;46:2027-29. PMid:11106349

[7] Maurice Pelsers MMAL, Moravat A, Alexander GJM, Hermens WT, Trull AK, Glatz JFC. [Technical briefs] Liver fatty acid-binding protein as a sensitive serum marker of acute hepatocellular damage in liver transplant recipients. Clin Chem. 2002;48:2055-57. PMid:12406996

[8] Hyans KC. Risks of chronicity following acute hepatitis B virus infection: a review. Clin Infect Dis. 1995; 20:992-1000. PMid:7795104 http://dx.doi.org/10.1093/clinids/20.4.992

[9] Zhang B-L, Han S-B, Yue Y-F. HBV viremia level of pregnant women and intrauterine infection: nested PCR for detection of HBV DNA. World Gastroenterol. 1998;4:61-63

[10] Okafor WN, Kaine GO. Hepatitis B surface antigen in Nigerian children with sickle cell anaemia. J Tropical Pediatr. 1983;29:55-57. PMid:6834464

[11] Ramia S, Hossain A, Bakir TM.F, Waller DK, Vivian PA. Prevalence and subtype of hepatitis B surface antigen (HBsAg) in the Saudi population. Trop Geogr Med. 1986;38:63-69. PMid:3961911

[12] Vichinsky E, Onyekwere O, Porter J, Swerdlow P, Eckman J, Lane P et al.. A randomized comparison of deferasirox versus deferoxamine for the treatment of transfusional iron overload in sickle cell disease. Br J Haematol. 2007;136:501-08. PMid:17233848 http://dx.doi.org/10.1111/j.1365-2141.2006.06455.x

[13] Owusu-Ofori S, Temple J, Sarkodie F, Anokwa M, Candotti D, Allain J-P. Predonation screening of blood donors with rapidtests: implementation and efficiency of a novel approach of blood safety in resource-poor settings. Transfusion 2005;45:133-40. PMid:15660820 http://dx.doi.org/10.1111/j.1537-2995.2004.04279.x

[14] Kato GJ, McGowan V, Machado RF, Little JA., Taylor J, VI, Morris CR. et al. Lactate dehydrogenase as a biomarker of haemolysis-associated nitric oxide resistance, priapism, leg ulceration, pulmonary hypertension and death in patients with sickle cell disease. Blood 2006;107:2279-85. PMid:16291595 http://dx.doi.org/10.1182/blood-2005-06-2373

[15] Jensen PD, Jensen FT, Christensen T, Nielsen JL, Ellegaard J. Relationship between hepatocellular injury and transfusional iron overload prior to and during iron chelation with desferrioxamine: a study in adult patients with acquired anemias. Blood 2003;101:91-96. PMid:12393528 http://dx.doi.org/10.1182/blood-2002-06-1704

[16] Sherwood P, Lyburn I, Brown S, Ryder S. How are abnormal results from liver function tests dealt with in primary care? Audit of yield and impact. Br Med J 2001;322:276-78. PMid:11157530 http://dx.doi.org/10.1136/bmj.322.7281.276

[17] Siroky MC, Krane KJ. Manual of Virology: Diagnosis and Therapy:Boston, Little Brown. 1990;37-38

[18] Haut MJ, Cowan DH, Harris JW. Platelet function and survival in sickle cell disease. J Lab Clin Med. 1973;82:44-53. PMid:4718003 